Situs Jurnal : $\underline{\text { http://ejournal.stiepancasetia.ac.id/index.php/jieb }}$

Jilid 5 Nomor 3 November 2019

Hal 371 - 385

\title{
PROGAM APLIKASI PENERIMA DAN PENGELUARAN KAS TERINTEGRASI PENGELOLAAN ASET TETAP BERWUJUD MENGGUNAKAN PHP PADA YAYASAN PENDIDIKAN BINA ILMU (YPBI) BANJARMASIN
}

\section{Muhammad Hendra Sunarya*, Ahsanul Haq, Nadia Puteri Utami, Khairunnisa, dan Dinah Aulia Putri}

\begin{abstract}
The purpose of this research is to find out the accounting information system for cash receipts and disbursements and asset management that is running on the Yayasan Pendidikan Bina Ilmu in accordance with the Internal Control System (SPI) and to build the acceptance application and integrated cash disbursement of tangible fixed asset management on the webbased application system. The theorical framework is to analyze the Accounting Information System that runs in educational institutions, namely by analyzing information needed by management, related functions, accounting documents and records used, and document flowchart (flowchart).The findings and results of this study are that the Yayasan Pendidikan Bina Ilmu (YPBI) we have built an application that will be able to produce reports on receipts, cash disbursements, depreciation reports and fixed assets cards effectively.
\end{abstract}

Keywords: Cash receipts and Disbursements, Internal Control Systems, Fixed Assets, Tangible Assets, Computerized

Abstrak: Tujuan penelitian ini adalah untuk membangun sistem informasi akuntasi penerimaan dan pengeluaran kas serta pengelolaan aset yang sedang berjalan pada Yayasan Pendidikan Bina Ilmu Banjarmasin sesuai dengan Sistem Pengendalian Intern (SPI). Kerangka pemikiran (teoritis) penelitian ini adalah menganalisis Sistem Informasi Akuntansi yang berjalan pada lembaga pendidikan, yaitu dengan menganalisis informasi yang diperlukan manajemen, fungsi yang terkait, dokumen dan catatan akuntansi yang digunakan, dan bagan alir dokumen (flowchart. Temuan dan hasil penelitian ini adalah bahwa Yayasan Pendidikan Bina Ilmu (YPBI) Banjarmasin selama pencatatan dalam penerimaan dan pengeluaran kas maupun pengelolaan asetnya sudah terkomputerisasi namun hanya menggunakan Ms. Excel. Kelemahan penerapan ini adalah membutuhkan waktu untuk proses pencatatan transaksi. Oleh karena itu dengan adanya program aplikasi yang dibuat pada penelitian ini diharapkan yayasan terbantu dalam menghasilkan laporan penerimaan, pengeluaran kas, laporan penyusutan aset dan kartu aset tetap secara efektif.

Kata kunci: Penerimaan dan Pengeluaran Kas, Aset Tetap, Aset Tetap Berwujud, Sistem Pengendalian Intern, Terkomputerisasi

\section{Latar Belakang}

Era sekarang setiap instansi/yayasan baik itu pemerintah maupun swasta dituntut untuk menyesuaikan diri dengan perkembangan teknologi yang begitu pesat. Begitu pula dalam proses pengelolan keuangan yang mana membutuhkan suatu sistem informasi. Salah satu sistem informasi adalah sistem informasi akuntansi. Sistem informsai akuntansi dalam instansi/yayasan sangat dibutuhkan sebagai alat untuk mengorganisasi, mengukur, 
mengidentifikasi, mencatat dan menyimpan informasi seperti halnya dalam pengolahan anggaran biaya layanan umum. Dengan adanya sistem informasi akuntansi tersebut sebuah instansi/yayasan dalam menghasilkan laporan keuangan yang cepat, tepat dan akurat.

Penerapan sistem akuntansi dalam sebuah instansi/yayasan dapat mengoptimalkan biaya operasional yang dikeluarkan, yaitu biaya belanja barang dan biaya gaji dan tunjangan. Salah satu sistem akuntansi yang digunakan oleh sebuah instansi/yayasan adalah sistem penerimaan dan pengeluaran kas (Shatu, 2016). Sistem ini menangani penerimaan dan pengeluaran kas yang terjadi setiap rutin pada sebuah instansi/yayasan. Penerapan sistem penerimaan dan pengeluaran kas ini berperan penting, mengingat kas adalah bagian aktiva paling likuid dan mudah berubah dibandingkan aktiva lain dalam menjalakan kegiatan usahanya.

Yayasan Pendidikan Bina Ilmu (YPBI) Banjarmasin merupakan yayasan yang bergerak dalam bidang pendidikan. Berdiri sejak tahun 1991 berdasarkan akta notaris Bertha Suriati Ihalauw Halim, SH nomor 7 tanggal 2 Oktober 1991 dan akta notaris Linda Kenari, SH, MH nomor 79 tanggal 19 Desember 2016. Pengesahan dari KEMENKUMHAM nomor AHUAH.01.06-0005056 tahun 2016. Beralamat di Jalan Pangeran Hidayatullah Banua Anyar Banjarmasin RT 14 Kelurahan Sungai Jingah Kecamatan Banjarmasin Utara. Yayasan Pendidikan Bina Ilmu sebagai pengelola STIMIK Indonesia Banjarmasin dalam pengelolaan data keuangannya sudah menggunakan semi komputerisasi, namun terbatas hanya menggunakan Microsoft Excel. Pengguna Microsoft Excel memiliki keterbatasan dan kelemahan, beberapa kelemahan tersebut diantaranya sistem pencatatan transaksi yang di input manual mengakibatkan kekacauan dalam laporan keuangan, sulitnya akses data dan informasi mengenai data penerimaan, pengeluaran kas dan pengelolaan aset tetap, serta adanya kesulitan dalam pembuatan laporan penerimaan, pengeluaran kas dan laporan penyusutan aset tetap. Beberapa kelemahan tersebut, berdampak pada tingkat keakuratan data, duplikasi data, ancaman terhadap validasi data dan sebagai media penyimpanan relatif kurang aman karena dapat digunakan oleh siapa saja.

Berdasarkan permasalahan yang diuraikan diatas, maka penulis tertarik untuk membangun sistem semi komputerisasi yang ada di YPBI Banjarmasin dengan membuatkan sebuah aplikasi berbasis web menggunakan PHP agar data dapat dikelola secara lebih teroganisir. Penggunaan aplikasi berbasis web dalam mengolah data akan lebih membantu dalam kegiatan penyusunan laporan penerimaan dan pengeluaran kas.

\section{Kajian Literatur}

Kas adalah aktiva yang likuid, medium standar dari pertukaran dan dasar untuk pengukuran dan akuntansi bagi item lainnya. Pada umumnya kas diklasifikasikan sebagai aktiva lancar. Kas terdiri dari koin, mata uang dan dana deposit pada bank. Kas dan setara kas dapat diartikan bersifat jangka pendek, investasi dengan tingkat likuiditas yang tinggi, siap diubah menjadi sejumlah kas yang diketahui jumlahnya dan sangat dekat dengan maturitas mereka yang merepresentasikan resiko tidak signifikan dari perubahan tingkat suku bunga (Kieso, Donald E, Wygandt, Jerry J, Warfield, 2010)

Sistem Akuntansi Penerimaan Kas adalah proses aliran kas yang terjadi di perusahaan adalah terus menerus sepanjang hidup perusahaan yang bersangkutan masih beroperasi. Aliran kas terdiri dari aliran kas masuk dan aliran kas keluar. Penerimaan kas perusahaan berasal dari dua sumber utama, yaitu penerimaan dari penjualan tunai dan penerimaan kas dari piutang atau dari penjualan secara kredit.

Sedangkan penerimaan kas pada sebuah Lembaga Pendidikan berasal dari sumber bantuan dana dari pemerintah, pembayaran per semester setiap bulannya, pembayaran uang pendaftaran, pembayaran uang fasilitas misalnya fasilitas gedung, buku, seragam dll. 
Berdasarkan pengertian tersebut dapat disimpulkan bahwa sistem akuntansi penerimaan kas adalah suatu kesatuan untuk mengumpulkan, mencatat transaksi yang dapat membantu pimpinan untuk menangani penerimaan perusahaan (Pasaribu, 2005)

Pembayaran kas dalam perusahaan dilakukan dengan menggunakan cek kecuali untuk pembayaran dalam kecil, biasanya dilaksanakan melalui dana kas kecil. Dana kas kecil ialah uang kas yang disediakan untuk membayar pengeluaran-pengeluaran yang jumlahnya relatif kecil dan tidak ekonomis bila dibayar dengan cek. Seperti halnya ongkos transport atau unit keperluan sehari-hari dimana pembayaran dengan cek untuk hal-hal yang sekecil itu akan mengakibatkan pekerjaan menjadi tertunda, membosankan, dan beban pencatatannya mahal. Dana kas kecil diserahkan kepada kasir kas kecil yang bertangung jawab untuk membayar biaya yang relatif kecil dan meminta pengisian kembali dari kas bersar.

Metode yang dapat digunakan dalam penyelenggaraan kas kecil ada dua, yaitu sebagai berikut :

1. Metode Fluktuasi

Metode ini pembentukan dana kas kecil dicatat dengan mendebit rekening dana kas kecil. Pengeluaran dana kas kecil dicatat dengan mengkredit rekening dana kas kecil, sehingga saldo rekening kas kecil selalu berubah. Dalam pengisian kembali dana kas kecil dilakukan sesuai dengan keperluan (tidak berdasarkan jumlah pengeluaran sebelumnya) dan dicatat dengan mendebbit rekening dana kas kecil.

\section{Metode Imprest}

Pembentukan dana kas kecil dengan metode ini dilakukan dengan cek dan dicetak dengan mendebit rekening dana kas kecil. Saldo kas kecil tidak berubag sesuai yang ditetapkan, kecuali jika saldo yang ditetapkan itu dinaikkan atau dikurangi. Pengeluaran dana kas kecil tidak divatat dalam jurnal tetapi hanya dilakukan dengan mengumpulkan bukti-bukti transaksi sebagai arsip sementara oleh pemegang kas kecil. Pengisian kembali dana kas kecil dilakukan sejumlah rupiah yang tercantum dalam kumpulan bukti pengeluaran kas kecil. Bukti pengeluaran ini dicap "telah dibayar" agar tidak digunakan lagi. Pengisian ini dilakukan dengan cek dan dicatat dengan mendebit rekening biaya dan mengkredit rekening kas. (Shatu, 2016).

"Sistem pengendalian intern meliputi struktur organisasi, metode dan ukuran - ukuran yang dikoordinasikan dalam menjaga kekayaan organisasi, mengecek ketelitian dan keandalan data akuntansi, mendorong efisiensi dan dipatuhinya kebijakan manajemen."(Mulyadi, 2016). Sistem pengendalian intern memiliki unsur pokok yaitu (Mulyadi, 2016):

1. Struktur organisasi yang memisahkan tanggung jawab fungsional secara tegas.

2. Sistem wewenang dan prosedur pencatatan yang memberikan perlindungan yang cukup terhadap kekayaan, utang, pedapatan, dan beban.

3. Praktik yang sehat dalam melaksanakan tugas dan fungsi setiap unit organisasi.

4. Karyawan yang mutunya sesuai dengan tanggung jawabnya.

Menurut (Pasaribu, 2005) aset tetap berwujud didefenisikan sebagai harta atau aset yayasan yang digunakan dalam proses menghasilkan pendapatan dan menjalankan kegiatan dalam mencapai tujuan Yayasan. Menurut (Baridwan, 2011) aset tetap adalah aset tetap berwujud yang dimiliki untuk digunakan dalam produksi atau penyediaan barang atau jasa, untuk disewakan kepada pihak lain atau untuk tujuan administratif dan diharapkan dapat digunakan lebih dari satu periode akuntansi. 
Untuk tujuan akuntansi dilakukan pengelompokan aset tetap berwujud sebagai berikut (Baridwan, 2011):

1. Aset tetap yang umurnya tidak terbatas seperti tanah untuk letak perusahaan.

2. Aset tetap yang umurnya terbatas dan apabila sudah habis masa manfaatnya bisa diganti dengan aset sejenis seperti bangunan, mesin, kendaraan, dan lain-lain.

3. Aset tetap yang umurnya terbatas dan apabila sudah habis masa manfaatnya tidak dapat diganti dengan aset sejenis seperti sumber alam (tambang, hutan,dan lain-lain).

Menurut Standar Akuntansi Keuangan tahun 2002 (PSAK No. 17) Ada beberapa metode yang dapat digunakan untuk menghitung beban depresiasi. Untuk dapat memilih salah satu metode hendaknya dipertimbangkan keadaan-keadaan yang mempengaruhi aset. Metodemetode itu ialah (IAI, 2017):

1. Metode garis lurus (straight line method)

2. Metode jam jasa (service hours method)

3. Metode hasil produksi (productive output method)

4. Metode beban berkurang (reducing charge method)

Ada cara untuk menghitung beban depresiasi atau penyusutan yang menurun dari tahun ke tahun yaitu:

1. Jumlah angka tahun (sum of year digits method)

2. Saldo menurun (declining balance method)

3. Saldo menurun ganda (double declining balance method)

a. Metode berdasarkan jenis dan kelompok (group and composite method)

b. Sistem persediaan (Inventory systems)

Sistem terdiri dari elemen-elemen yang saling berhubungan membentuk satu kesatuan untuk melaksanakan suatu tujuan pokok dari sistem tersebut. (Pawirosumarto 2008). Sistem adalah kumpulan dari dua atau lebih komponen yang saling bekerja dan berhubungan untuk mencapai tujuan tertentu dan perusahaan adalah sebuah sistem yang terdiri dari beberapa dapertemen yang bertindak sebagai subsistem yang membentuk sistem perusahaan tersebut (Mulyani, 2016). Sistem bisa diartikan sebagai sekumpulan subsistem, komponen ataupun elemen yang saling berkerjasama dengan tujuan yang sama untuk menghasilkan output yang sudah di tentukan sebelumnya (Mulyadi, 2016). Komputer adalah setiap mesin yang mampu menerima data, memproses data, menyimpan data, dan menghasilkan bentuk keluaran berupa teks, gambar, simbol, angka, dan suara. (Pawirosumarto, 2008)

Definisi di atas dapat diberi kesimpulan sistem komputer adalah suatu sistem yang dibentuk sedemikian rupa agar komputer dapat melakukan pengolahan data. Tujuan pokok dari sistem komputer adalah mengolah data untuk menghasilkan informasi yang perlu didukung oleh elemen-elemen yang terdiri dari perangkat keras (hardware), perangkat lunak (software), dan brainware.

\section{Metode Penelitian}

Metode penelitian yang digunakan adalah waterfall. Metode waterfall merupakan salah satu metode dalam System Development Life Cycle (SDLC) yang melibatkan beberapa langkah dalam aktivitas pembangunan sistem yaitu tahap requirement termasuk pengumpulan data, analisis dan desain dan terakhir proses evaluasi (Adetokunbo A.A. Adenowo, 2013).

Tahap requirement dilakukan dengan cara melakukakan observasi terhadap sistem yang telah berjalan, format yang digunakan, pengguna sistem serta alur proses yang telah diterapkan. Pada kasus ini kami melakukan observasi terhadap proses bisnis dan beberapa form serta bentuk 
laporan yang telah digunakan oleh pengguna sistem. Dari proses ini kami lanjutkan dengan tahap analisis dimana kami lakukan perancangan terhadap alur proses sistem yang kami wujudkan ilustrasi bagan alir / flowchart, diagram konteks, desain entity diagram, desain database dan perancangan aplikasi.

Kemudian tahapan akhir adalah proses evaluasi dari langkah-langkah yang telah kami terapkan sebelumnya melalui serangkaian tes atau pengujian terhadap fitur aplikasi yang telah kami buat.

\section{Hasil Penelitian}

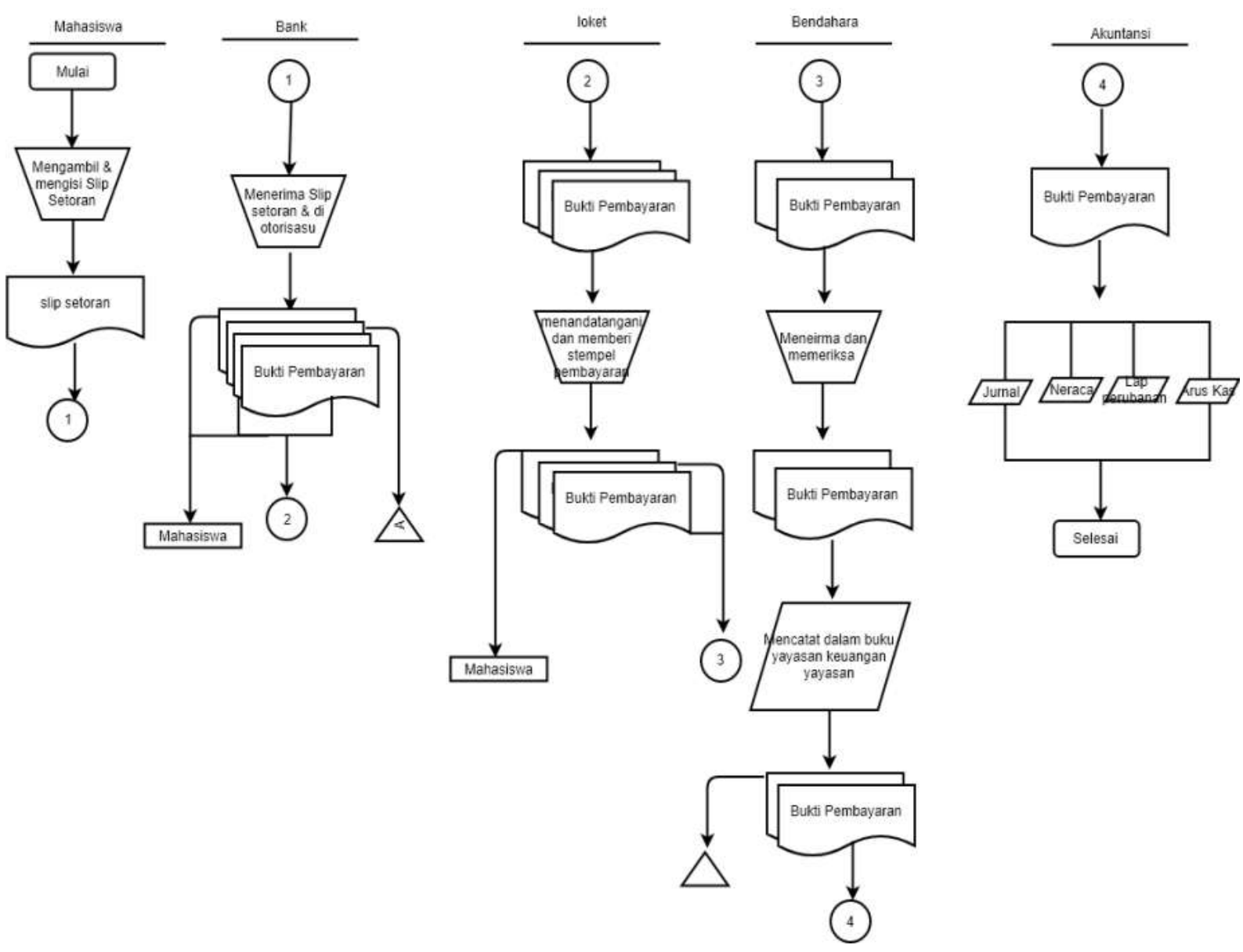

\section{Gambar 1. Penerimaan Kas dari Pembayaran SPP}

Untuk pengadaan aset tetap, yayasan menerima surat permohonan pengadaan aset tetap dari bagian atau unit yang memerlukan. Kemudian yayasan memproses untuk persetujuan pengadaan aset tetap. Apabila disetujui oleh ketua yayasan untuk pembelian aset, yayasan akan mengirim surat balasan kepada bagian atau unit yang memerlukan bahwa permohonan pengadaan aset disetujui. Selanjutnya yayasan akan memerintahkan bendahara untuk membelikan aset tetap tersebut. Setelahnya aset yang dibeli datang, lalu dicatat oleh bagian yang menerimanya lalu laporannya diberikan kepada yayasan sebagai bukti transaksi pembelian aset. Untuk pengelolaan aset tersebut yayasan hanya mencatatnya di Microsoft Excel laporan yang dibuat hanya berupa penempatan aset, kondisi, tahun pembelian, dan nama aset. 

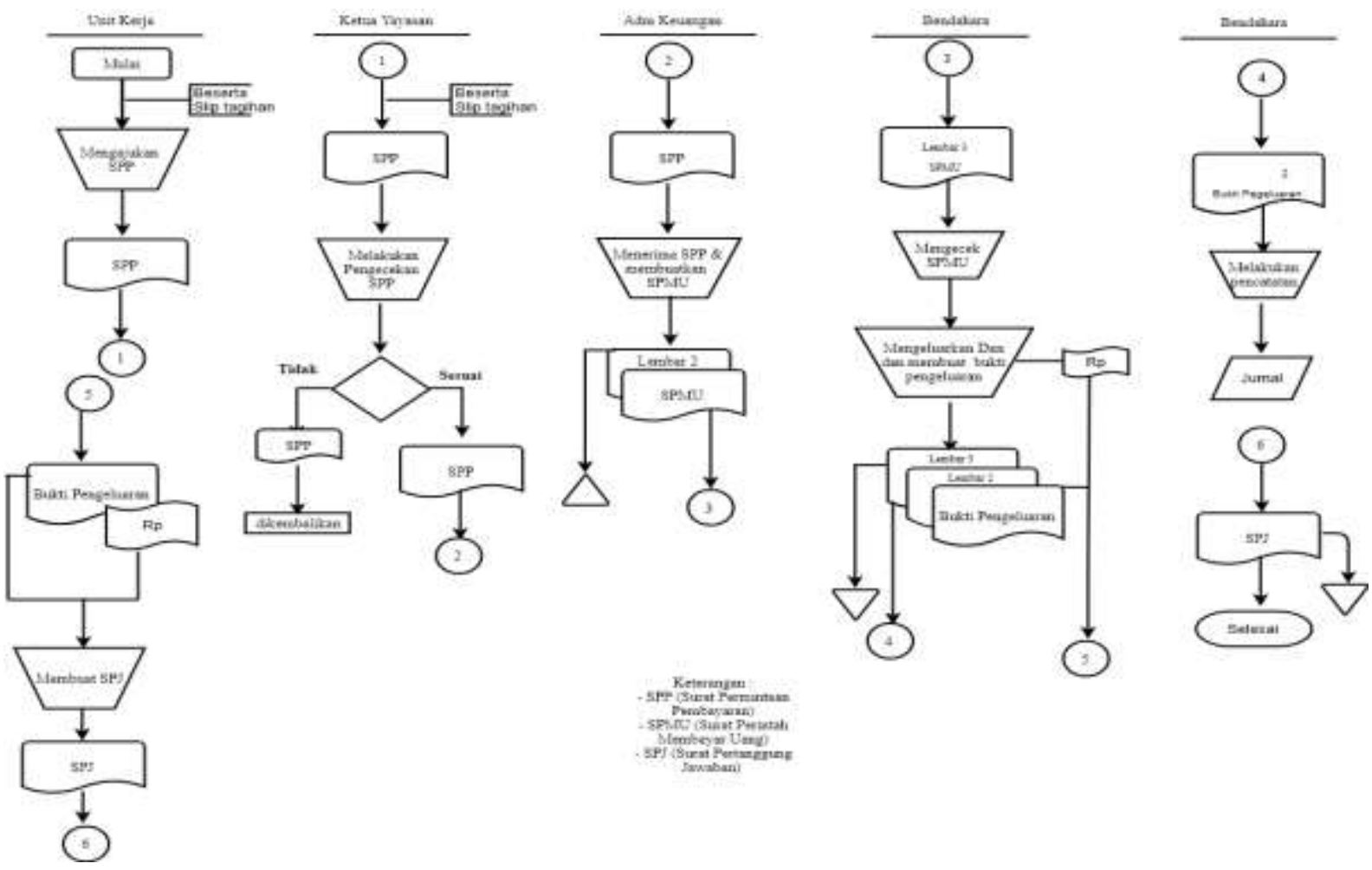

Gambar 2. Pengeluaran Kas
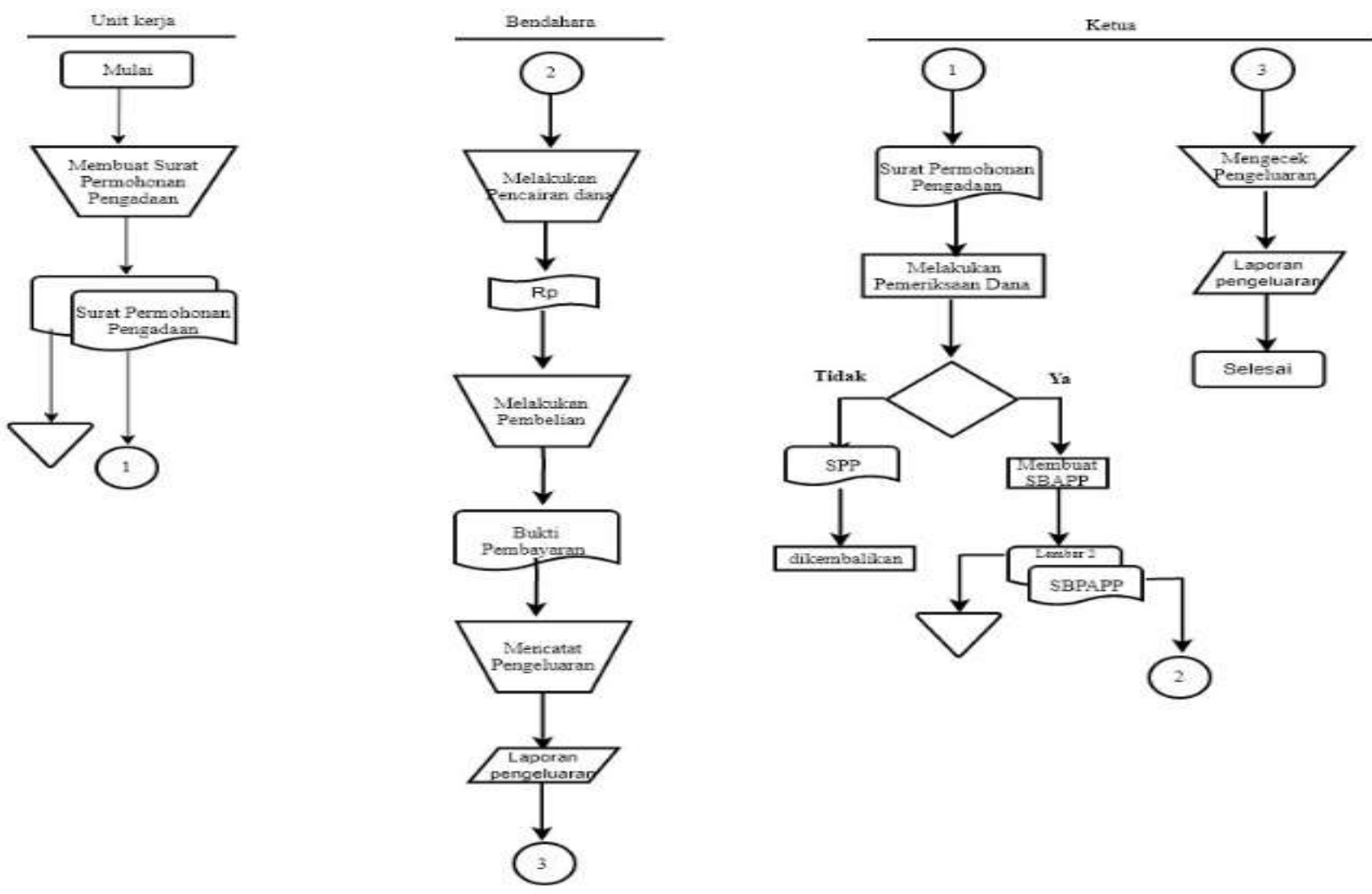


\section{Gambar 3. Integrasi fungsi kas dan fungsi aset}

Diagram konteks, Data Flow Diagram (DFD) Level Nol (0), hingga Entry Relationship Diagram (RRD) dalam penelitian ini ditunjukkan pada Gambar 4 sampai dengan Gambar 9..

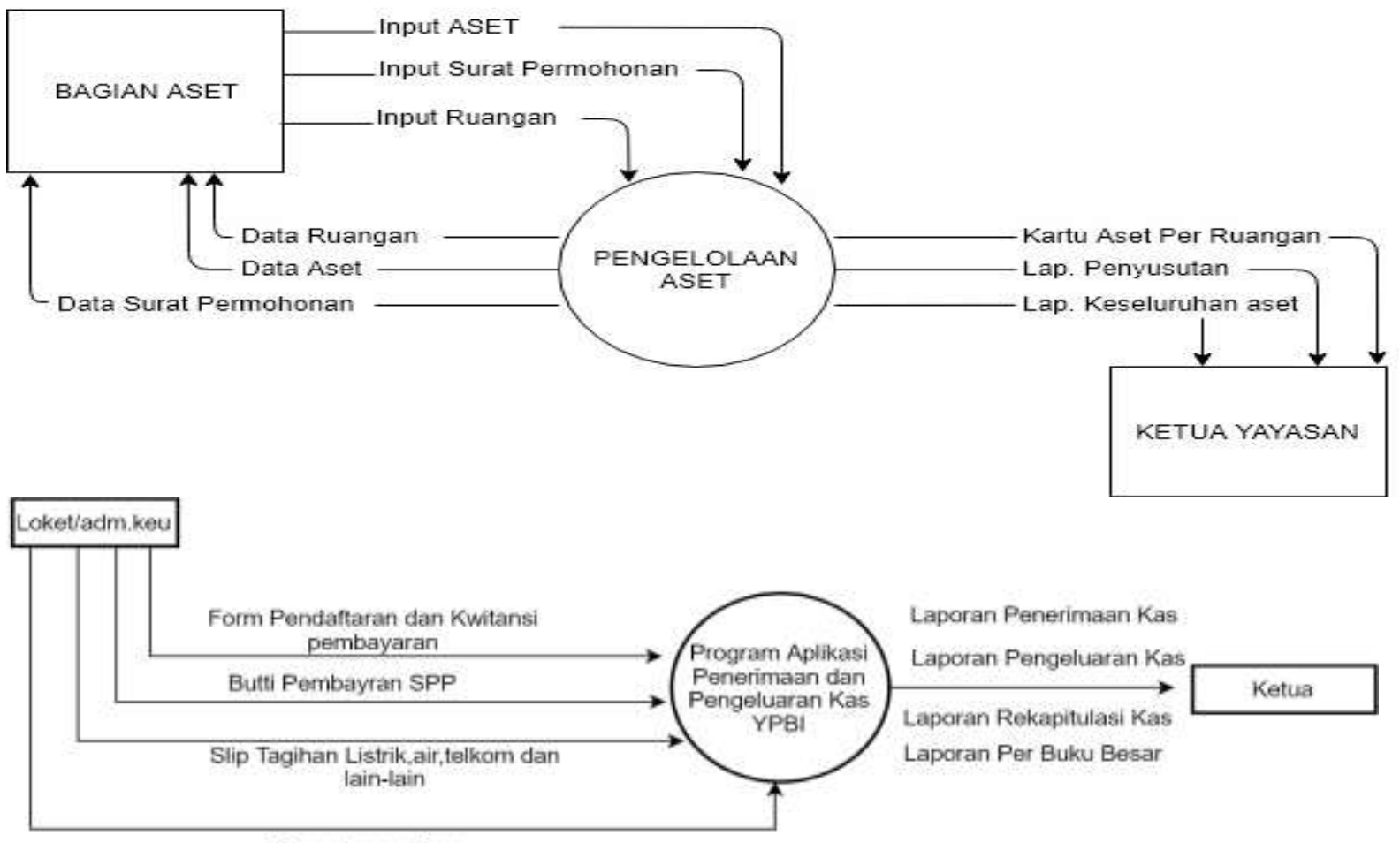

Permohonan Dana

\section{Gambar 4. Diagram konteks}

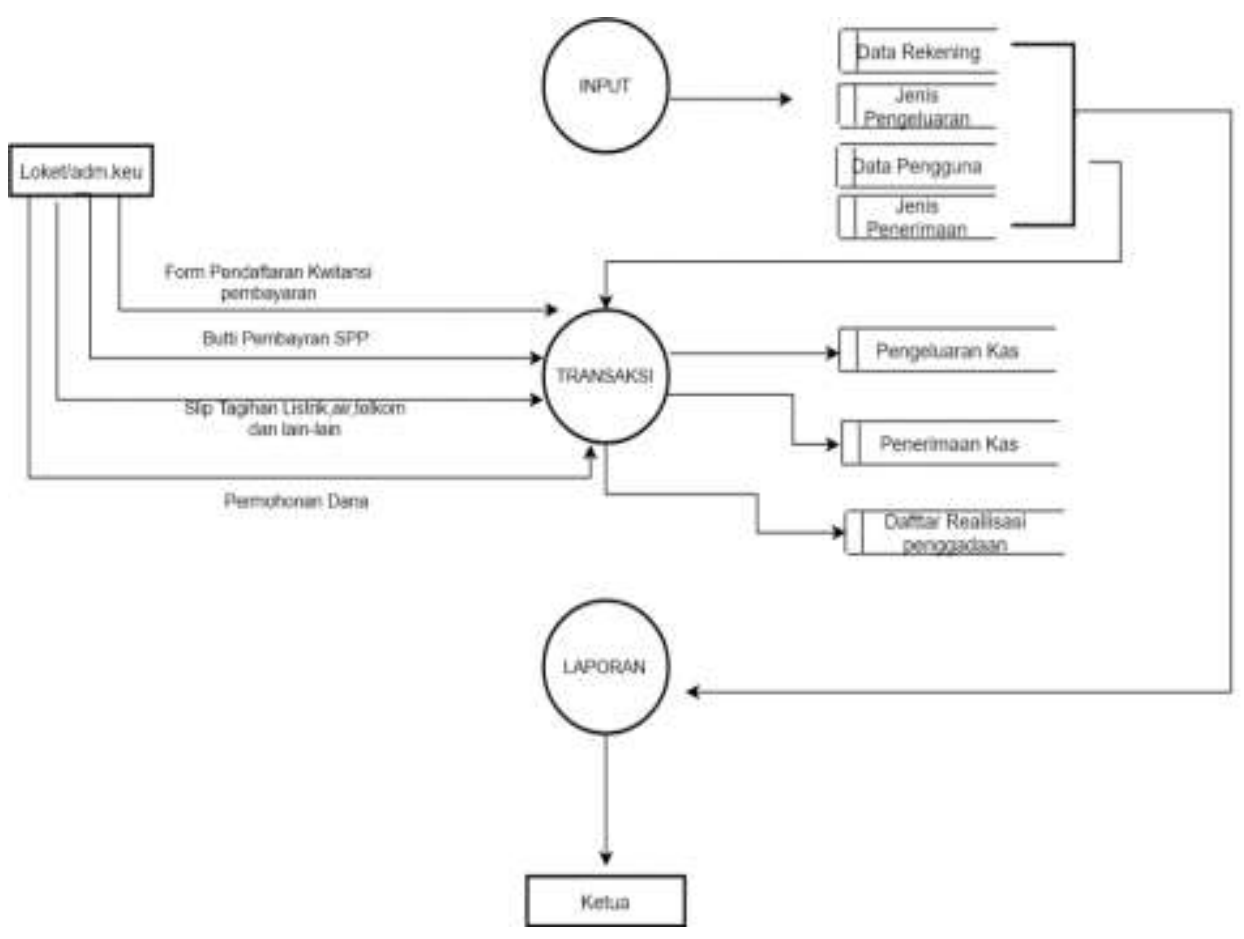

Gambar 5 : DFD Level 0 


\section{DFD LEVEL 0}

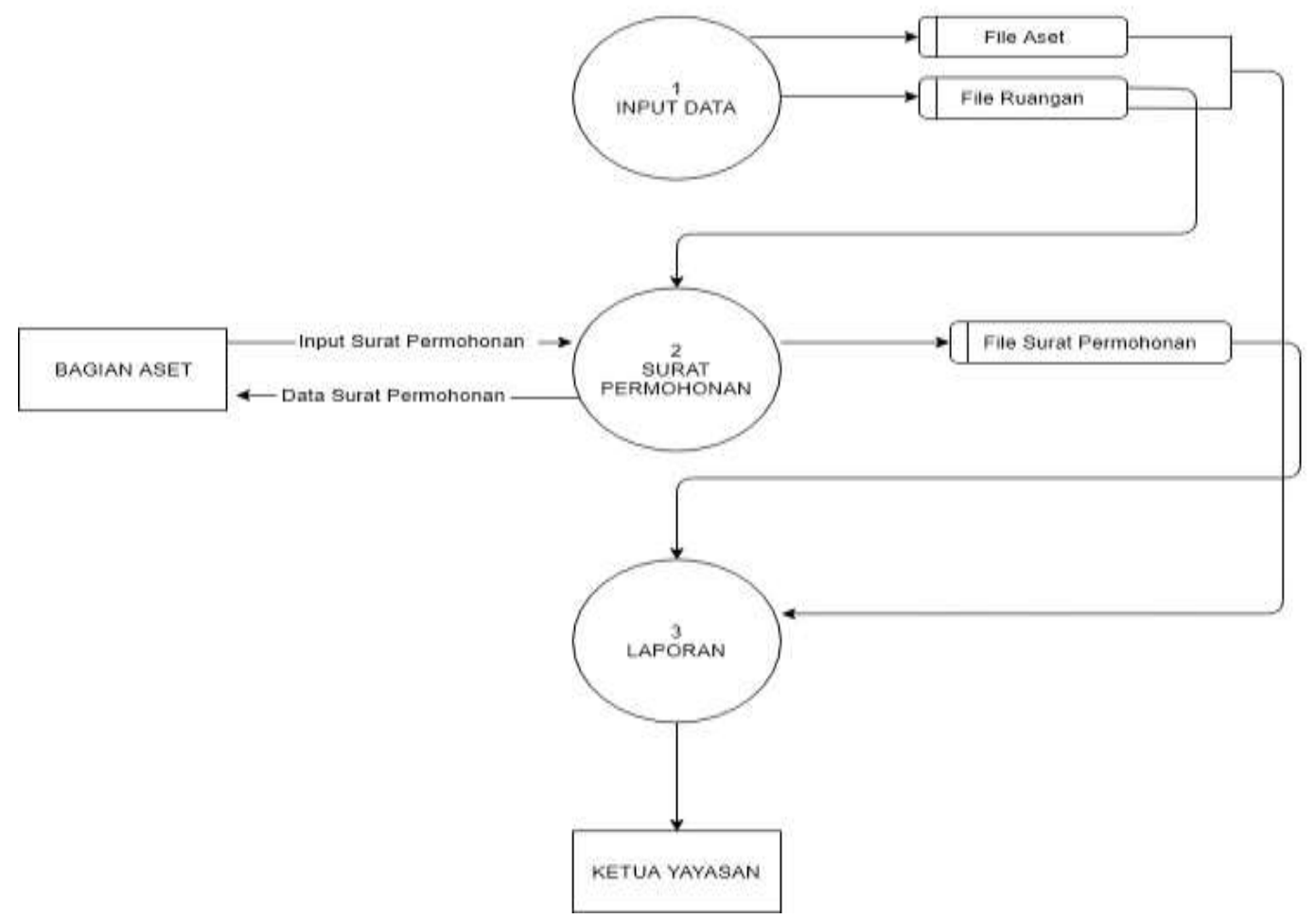

Gambar 6. Diagram level 0 pada bagian aplikasi asset
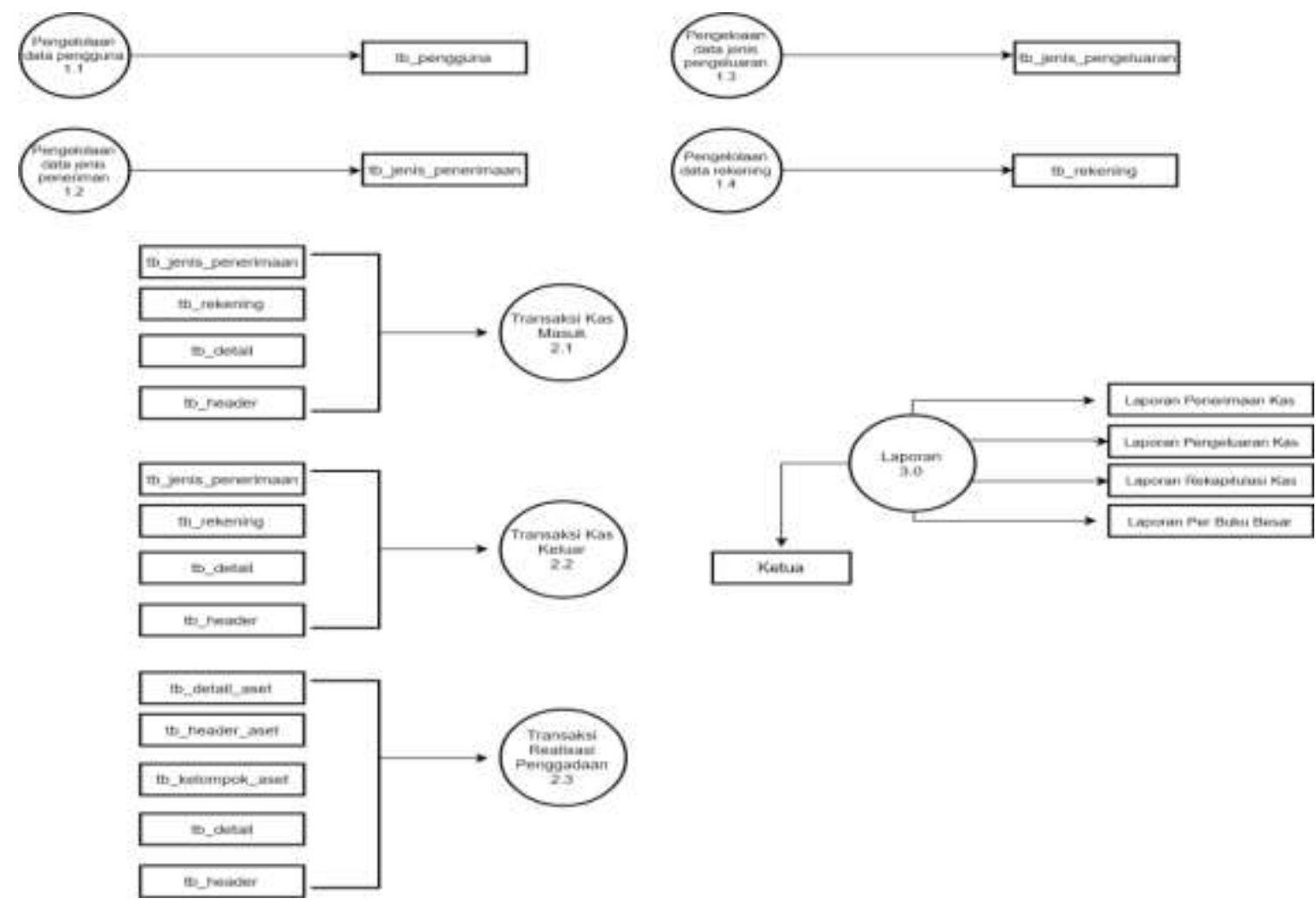

Gambar 7 : DFD Level 1 


\section{DFD LEVEL 1}
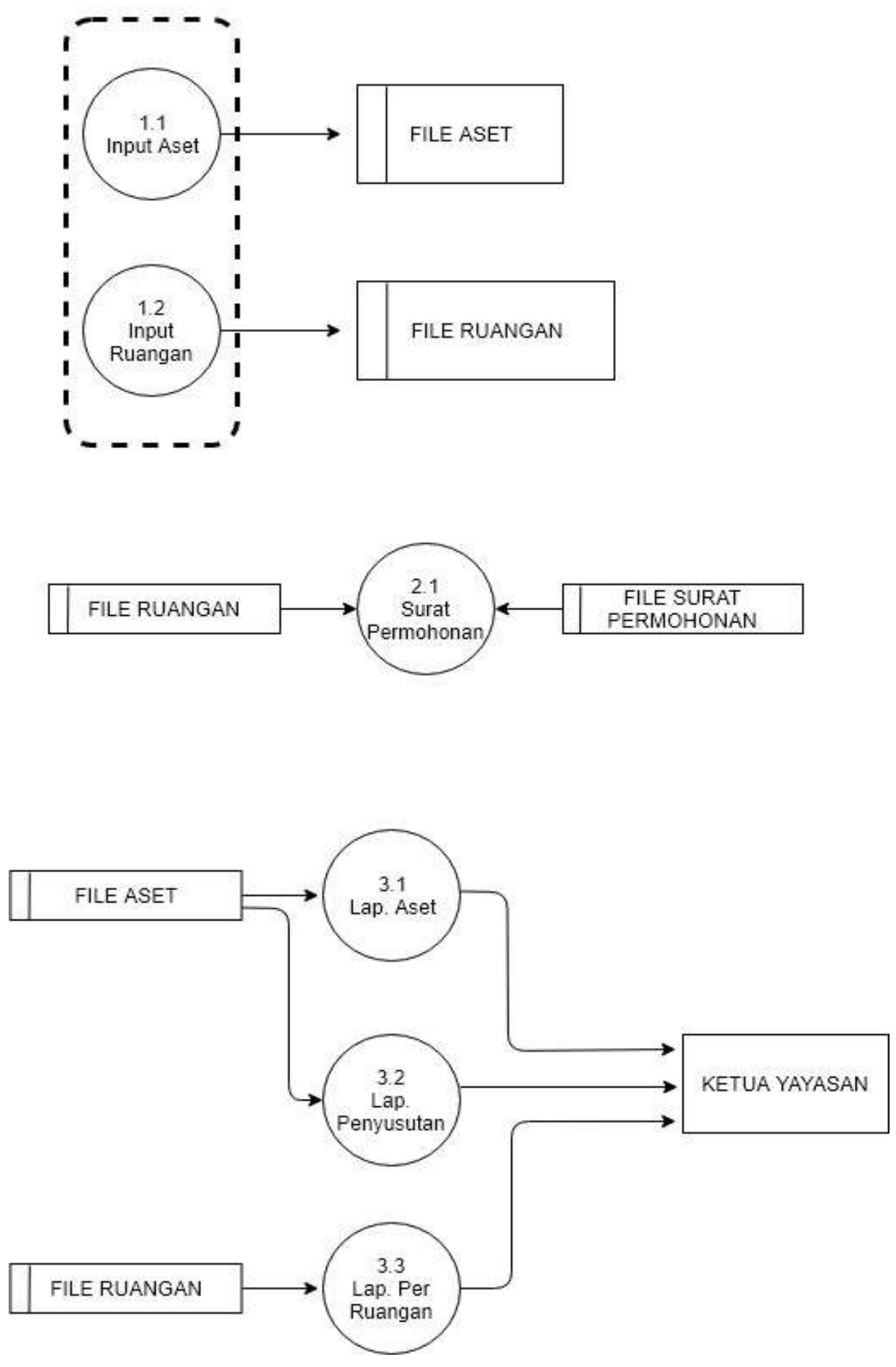

Gambar 8 : DFD Level 1 Aset 


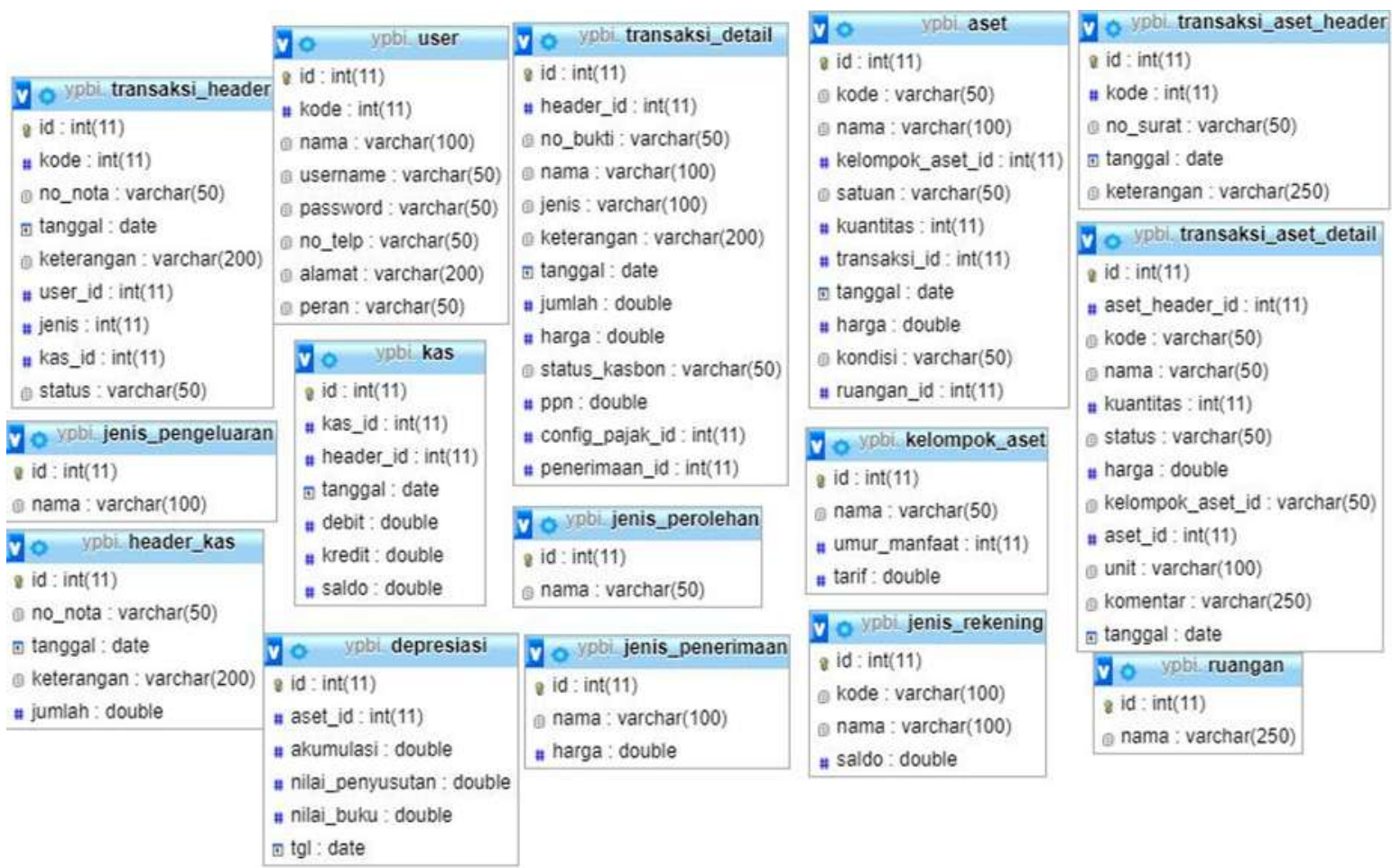

\section{Gambar 9. Entity Relationship Diagram (ERD)} berikut:

Penjelasan dari gambar relasi antar tabel seperti telah dicantumkan diatas adalah sebagai

1. Tabel Jenis Rekening

Tabel rekening_kas adalah tabel yang digunakan untuk menyimpan data rekening kas yang dipakai dan menambahkan data jenis barang yang baru. Tabel ini memiliki jenis relasi one to many ke tabel transaksi_header dengan field kunci id. Hal ini berarti bahwa satu jenis rekening kas bisa mempunyai banyak transaksaki pada tabel transaksi_header.

2. Tabel Jenis Penerimaan

Tabel jenis penerimaan adalah tabel yang digunakan untuk menyimpan data jenis penerimaan dan menambahkan data jenis penerimaan yang baru. Tabel ini memiliki jenis relasi one to many ke tabel jenis penerimaan dengan field kunci id. Hal ini berarti bahwa satu jenis kode jenis bisa mempunyai banyak detail kode pada tabel tb transaksi_detail.

3. Tabel Jenis Pengeluaran

Tabel jenis pengeluaran adalah tabel yang digunakan untuk menyimpan data jenis pengeluaran dan menambahkan data jenis pengeluaran yang baru. Tabel ini memiliki jenis relasi one to many ke tabel jenis penerimaan dengan field kunci id. Hal ini berarti bahwa satu jenis kode jenis bisa mempunyai banyak detail kode pada tabel tb transaksi_detail.

4. Tabel transaksi_detail

Tabel transaksi_detail adalah tabel yang digunakan untuk menyimpan data detail transaksi dan menambahkan data detail yang baru. Tabel ini memiliki jenis relasi many to one ke tabel 
transaksi_header dengan field kunci id. Hal ini berarti bahwa beberapa kode transaksi detail mempunyai satu transaksi pada tabel transaksi_header.

5. Tabel transaksi_header

Tabel transaksi_header adalah tabel yang digunakan untuk menyimpan data transaksi header dan menambahkan data header yang baru. Tabel ini memiliki jenis relasi one to many ke tabel transaksi_detail dengan field kunci id. Hal ini berarti bahwa satu jenis kode header bisa mempunyai banyak transaksi pada tabel transaksi_detail.

\section{Tabel asset}

Tabel aset adalah tabel yang digunakan untuk menyimpan dan menambahkan aset. Tabel ini memiliki relasi one to one dengan tabel kelompok_aset dengan field kunci id dan tabel ruangan dengan field kunci id. Hal ini berarti bahwa satu jenis kelompok_aset_id mempunyai satu aset di tabel aset.

7. Tabel depresiasi

Tabel depresiasi adalah tabel yang digunakan untuk menyimpan dan menambahkan depresiasi. Tabel ini memiliki relasi one to one dengan tabel aset dengan field kunci id. Hal ini berarti satu jenis aset mempunyai satu depresiasi di tabel depresiasi.

8. Tabel kelompok_aset

Tabel kelompok_aset adalah tabel yang digunakan untuk menyimpan kelompok_aset. Tabel ini memiliki relasi one to many dengan tabel aset dengan field id. Hal ini berarti bahwa satu kelompok_aset memiliki banyak aset di tabel aset.

9. Tabel ruangan

Tabel ruangan adalah tabel yang digunakan untuk menyimpan data ruangan. Tabel ini memiliki relasi one to many dengan tabel aset dengan field id. Hal ini berarti bahwa satu ruangan memiliki banyak aset di tabel aset.

10. Tabel transaksi_aset_header

Tabel transaksi_aset_header adalah tabel yang digunakan untuk menyimpan dan menambahkan transaksi_aset_header seperti no_surat, tanggal, dan keterangan. Tabel ini memiliki relasi one to many dengan tabel transaksi_aset_detail. Hal ini berarti bahwa satu transaksi_aset_header memiliki banyak transaksi aset detail di tabel transaksi_aset_detail.

11. Tabel transaksi_aset_detail

Tabel transaksi_aset_detail adalah tabel yang digunakan untuk menyimpan dan menambahkan transaksi_aset_detail seperti kode_aset, nama_aset, kelompok aset, kuantitas, status dan unit atau bagian yang memerlukan. Tabel ini memiliki relasi many to one dengan tabel transaksi_aset_header. Hal ini berarti bahwa banyak transaksi_aset_detail memiliki satu transaksi aset header di tabel transaksi_aset_header.

12. Tabel pengguna

Tabel pengguna adalah tabel yang digunakan untuk menyimpan data pegguna dan menambahkan data pengguna yang baru. Tabel ini memiliki jenis relasi one to many ke tabel transaksi_header dengan field kunci id. Hal ini berarti bahwa satu jenis kode pegawai bisa mempunyai banyak transaksi pada tabel transaksi_header. 
Desain tampilan adalah tampilan antar muka yang ada dilayar komputer sebagai bentukbentuk komunikasi antara pengguna dengan komputer. Terdapat dua user untuk menggunakan aplikasi ini. Dibawah ini merupakan tampilan program aplikasi persediaan barang dagangan menggunakan rumus biaya rata-rata tertimbang-perpetual yang telah penulis buat adalah sebagai berikut :

1. Form login adalah halaman yang pertama kali tampil apabila program dijalankan. Gambar dibawah ini merupakan form login yang penulis buat. User kas ialah user yang menjalankan fungsi kas atau yang biasa disebut bendahara, tugasnya berhubungan dengan penerimaan dan pengeluaran kas. User aset ialah user yang menjalankan fungsi kas atau bagian dari administrasi umum. Tugasnya berhubungan dengan permohonan pengadaan, penyusutan dan pengelolaan aset.
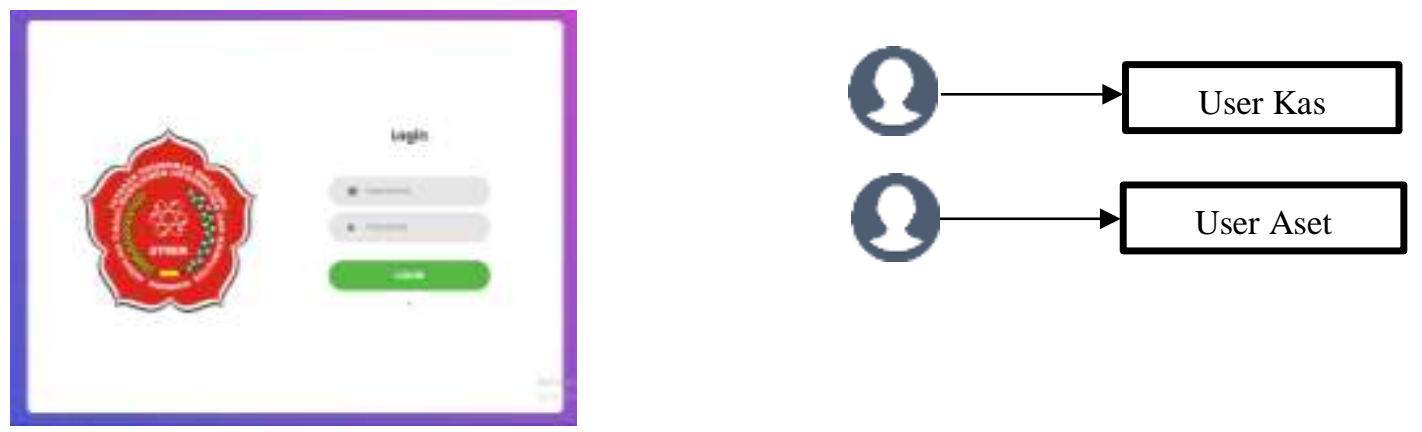

\section{Gambar 10. Form Login}

\section{Menu Utama}

Menu utama ini akan memudahkan pengguna dalam mengakses menu yang ingin ditampilkan. Menu utama ini juga terdiri dari sub-sub menu, dibawah ini merupakan form menu utama yang dibuat oleh penulis

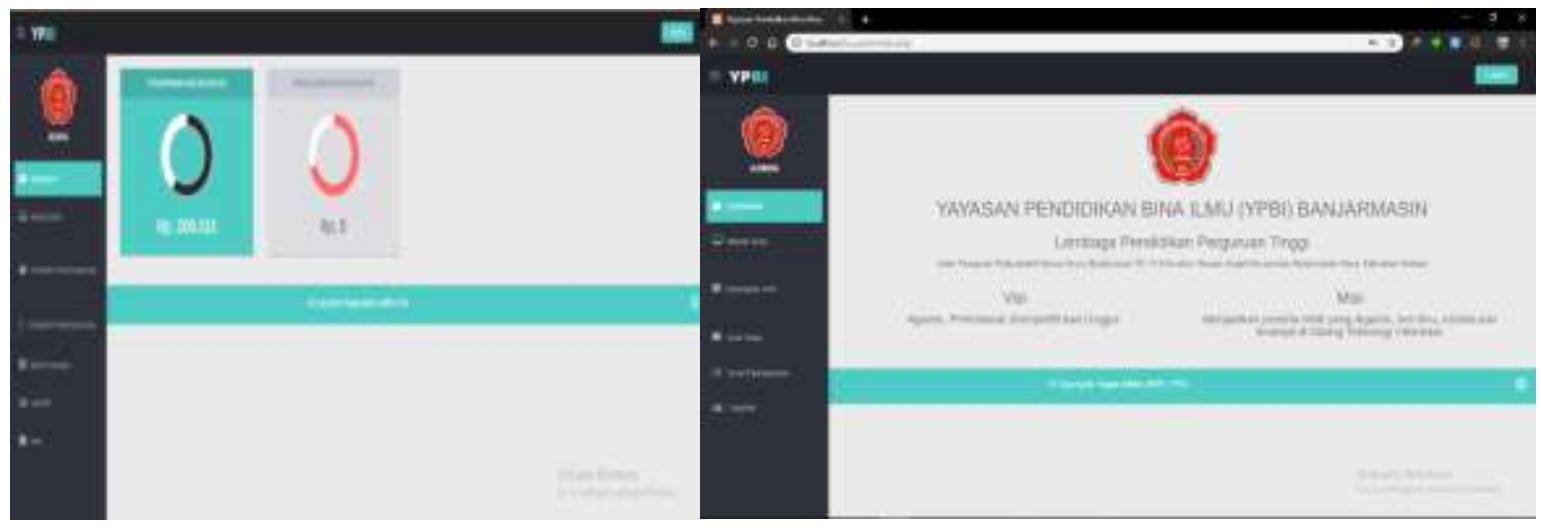

\section{Gambar 11. Form Menu Utama}

\section{Master Data}

Master data dipisahkan menjadi empat bagian yang berisi berbagai informasi utama, seperti informasi daftar rekenig, jenis penerimaan, jenis pengeluaran dan data pengguna. Pada daftar master data setiap data bisa ditambahkan, diubah, dan dihapus. 
4. Form Transaksi Penerimaan Kas

Form transaksi Penerimaan kas merupakan form yang digunakan pada saat terjadinya transaksi penerimaan kas dan pengguna mengisikan data transaksi sesuai dengan jenis penerimaan yang di cantumkan di dalm form transaki penerimaan kas.

5. Form Transaksi Pengeluaran Kas

Form transaksi Pengeluaran kas merupakan form yang digunakan pada saat terjadinya transaksi pengeluaran kas maupun melakukan biaya operasional.

6. Pengguna

Menu ini berisi daftar penguna yang dapat mengakses program aplikasi yang telah dibuat, dilengkapi dengan form penambahan pegawai baru, dna form edit atau hapus.

7. Form Daftar Transaksi

Daftar transaksi berisi berbagai informasi transaksi yang terjadi pada Yayasan Pendidikan Bina Ilmu, daftar transaksi terbagi menjadi 2 sub menu, yang berisi daftar penerimaan dan pengeluaran kas.

8. Laporan

Menu laporan berfungsi untuk melihat dan mencetak berbagai laporan untuk keperluan Yayasan Pendidikan Bina Ilmu(YPBI), laporan terbagi menjadi beberapa sub mennu seperti laporan pengeluaran dan penerimaan kas pertanggal, laporan kas, laporan umum kas

9. Master Aset Tetap

Master aset tetap digunakan untuk menyimpan data - data aset tetap milik Yayasan

10. Master Kelompok Aset

Master kelompok aset digunakan untuk menyimpan informasi kelompok aset seperti id, nama, masa manfaat, dan tarif

11. Surat Permohonan Pengadaan

Surat permohonan pengadaan adalah menu yang digunakan untuk melakukan pengadaan aset tetap.

12. Daftar Surat Permohonan Pengadaan

Daftar surat permohonan pengadaan adalah menu yang digunakan untuk melihat seluruh surat permohonan pengadaan.

13. Laporan Aset Tetap

Laporan aset tetap ialah laporan keseluruhan mengenai aset tetap yang dimiliki yayasan.

14. Laporan Penyusutan Aset

Laporan penyusutan aset adalah laporan mengenai penyusutan aset yang dilakukan setiap bulan ataupun setiap tahun.

15. Kartu Aset Per Ruangan

Kartu aset per ruangan ialah laporan mengenai aset apa saja yang berada pada setiap ruangan yang ada di yayasan. 
Hasil dari pengujian sistem dapat ditunjukkan pada Tabel 1.

Tabel 1. Tabel Pengujian Sistem

\begin{tabular}{|c|c|c|c|c|c|}
\hline \multirow[t]{2}{*}{ No } & \multirow[t]{2}{*}{ Kategori Yang di uji } & \multirow[t]{2}{*}{ Pertanyaan } & \multicolumn{2}{|c|}{ Jawaban } & \multirow[t]{2}{*}{ Saran } \\
\hline & & & Ya & Tidak & \\
\hline 1 & Login & $\begin{array}{l}\text { Apakah Fungsi login ke dalam sistem } \\
\text { sudah berfungsi benar? }\end{array}$ & $\sqrt{ }$ & & \\
\hline 2 & Menu Dashboard & $\begin{array}{l}\text { Apakah dashboard dapat difungsikan } \\
\text { ? }\end{array}$ & $\sqrt{ }$ & & \\
\hline 3 & $\begin{array}{l}\text { Menu Rekening } \\
\text { (Tambah,Edit,Hapus) }\end{array}$ & $\begin{array}{l}\text { Apakah Menu Rekening dapat } \\
\text { difungsikan? }\end{array}$ & $\sqrt{ }$ & & \\
\hline 4 & $\begin{array}{l}\text { Menu Jenis Peneriman } \\
\text { (Tambah,Edit,Hapus) }\end{array}$ & $\begin{array}{l}\text { Apakah Menu Jenis Peneriman dapat } \\
\text { difungsikan? }\end{array}$ & $\sqrt{ }$ & & \\
\hline 5 & $\begin{array}{l}\text { Menu Jenis Pengeluaran } \\
\text { (Tambah,Edit,Hapus) }\end{array}$ & $\begin{array}{l}\text { Apakah Menu Jenis Pengeluaran } \\
\text { dapat difungsikan? }\end{array}$ & $\sqrt{ }$ & & \\
\hline 6 & $\begin{array}{l}\text { Menu Pengguna } \\
\text { (Tambah,Edit,Hapus) }\end{array}$ & $\begin{array}{l}\text { Apakah Menu Pengguna dapat } \\
\text { difungsikan? }\end{array}$ & $\sqrt{ }$ & & \\
\hline 7 & $\begin{array}{l}\text { Transaksi Penerimaan } \\
\text { Kas }\end{array}$ & $\begin{array}{l}\text { Apakah Fungsi Transasksi } \\
\text { penerimaan kas ke dalam sistem } \\
\text { sudah berfungsi benar? }\end{array}$ & $\sqrt{ }$ & & $\begin{array}{l}\text { Tambahkan } \\
\text { Saldo } \\
\text { befluktuasi } \\
\text { Rekap di } \\
\text { daftar transksi }\end{array}$ \\
\hline 8 & $\begin{array}{l}\text { Transaksi Pengeluaran } \\
\text { Kas }\end{array}$ & $\begin{array}{l}\text { Apakah Fungsi Transasksi } \\
\text { pengeluaran kas ke dalam sistem } \\
\text { sudah berfungsi benar? }\end{array}$ & $\sqrt{ }$ & & $\begin{array}{l}\text { Tambahkan } \\
\text { Saldo } \\
\text { befluktuasi } \\
\text { Rekap di } \\
\text { daftar } \\
\text { transaksi }\end{array}$ \\
\hline 9 & $\begin{array}{l}\text { Penggadaan permohonan } \\
\text { aset }\end{array}$ & $\begin{array}{l}\text { Apakah Fungsi Penggadaan } \\
\text { permohonan aset ke dalam sistem } \\
\text { sudah berfungsi benar? }\end{array}$ & $\sqrt{ }$ & & \\
\hline \multirow[t]{2}{*}{ No } & \multirow[t]{2}{*}{ Kategori Yang di uji } & \multirow[t]{2}{*}{ Pertanyaan } & \multicolumn{2}{|c|}{ Jawaban } & Saran \\
\hline & & & Ya & Tidak & \\
\hline 1 & Login & $\begin{array}{l}\text { Apakah Fungsi login ke dalam sistem } \\
\text { sudah berfungsi benar? }\end{array}$ & $\sqrt{ }$ & & \\
\hline 2 & Menu Dashboard & Apakah dashboard dapat difungsikan? & $\sqrt{ }$ & & \\
\hline 3 & Menu Kelompok Aset & $\begin{array}{l}\text { Apakah Menu Kelompok Aset dapat } \\
\text { difungsikan? }\end{array}$ & $\sqrt{ }$ & & \\
\hline 4 & $\begin{array}{l}\text { Menu Aset } \\
\text { (Tambah,Edit,Hapus) }\end{array}$ & Apakah Menu Aset dapat difungsikan? & $\sqrt{ }$ & & \\
\hline 5 & $\begin{array}{l}\text { Menu Ruangan } \\
\text { (Tambah,Edit,Hapus) }\end{array}$ & $\begin{array}{l}\text { Apakah Menu Ruangan dapat } \\
\text { difungsikan? }\end{array}$ & $\sqrt{ }$ & & \\
\hline 6 & $\begin{array}{l}\text { Menu Pengguna } \\
\text { (Tambah,Edit,Hapus) }\end{array}$ & $\begin{array}{l}\text { Apakah Menu Pengguna dapat } \\
\text { difungsikan? }\end{array}$ & $\sqrt{ }$ & & \\
\hline 7 & Surat Permohonan & $\begin{array}{l}\text { Apakah Fungsi Surat Permohonan ke } \\
\text { dalam sistem sudah berfungsi benar? }\end{array}$ & $\sqrt{ }$ & & \\
\hline 8 & Depresiasi Aset & $\begin{array}{l}\text { Apakah Fungsi Depresiasi ke dalam } \\
\text { sistem sudah berfungsi benar? }\end{array}$ & $\sqrt{ }$ & & $\begin{array}{l}\text { Nilai } \\
\text { Penyusutan, } \\
\text { Akumulasi, } \\
\text { dan Nilai Sisa } \\
\text { dibuat } \\
\text { otomatis }\end{array}$ \\
\hline
\end{tabular}




\section{Diskusi}

Penelitian ini berfokus pada pembangunan aplikasi dalam mendukung penerapan sistem informasi akuntansi secara terkomputerisasi, berdasarkan prinsip-prinsip SPI dan dibangun sesuai dengan kebutuhan spesifik pada YPBI. Dengan adanya aplikasi yang telah dibangun maka kami berharap bahwa YPBI dalam memanfaatkan fitur yang ada pada aplikasi agar proses pengelolaan kas dapat dikelola secara lebih baik karena sistem mefasilitasi adanya validasi terhadap proses entri, terdokumentasinya proses serta terwujudnya data terpusat terhadap pengelolaan data. Adanya data yang terorganisir ini dapat membantu manajemen dalam menganalisis arus kas dalam periode tertentu, sebagai alat bantu dalam penentuan anggaran serta dapat menentukan prioritas terhadap pengelolaan kas di masa mendatang.

\section{Kesimpulan dan Keterbatasan Penelitian}

Sistem informasi penerimaan dan pengeluaran kas pada Yayasan Pendidikan Bina Ilmu Banjarmasin sudah berjalan dengan baik dengan adanya sistem pengendalian intern dalam pemisahan Fungsi pencatatan dan penyimpanan kas. Yang mana pencatatan dilakukan oleh bagian akuntansi dan penyimpanan kas dilakukan oleh bendahara.

Rancang bangun Program Aplikasi Penerimaan dan Pengeluaran Kas Terintegrasi Pengelolaan Aset Tetap Menggunakan PHP pada Yayasan Pendidikan Bina Ilmu (YPBI) Banjarmasin dibuat sesuai siklus akuntansi, yaitu dari dokumen transaksi yang diinput kedalam pemasukan dan pengeluaran, kemudian dibuatkan ouput berupa laporan buku besar, pemasukan dan pengeluaran kas.

Keterbatasan sistem ini meliputi aplikasi yang kami bangun masih dalam skala local (localhost) atau tidak secara online dapat digunakan. Hal ini terkait dengan waktu yang dibutuhkan oleh kami dalam proses rancang bangun tersebut.

Saran kami dengan adanya Program Aplikasi Penerimaan dan Pengeluaran Kas ini, diharapkan adanya upaya pengembangan lebih lanjut menjadi sistem informasi penerimaan dan pengeluaran kas yang lebih sempurna dengan fitur-fitur terbaru yang nantinya akan semakin memudahkan proses olahan data-data pembayaran, penggajian, dan pembuatan laporan. Aplikasi ini juga dapat diintegrasikan pada sistem lainnya sehingga pada akhirnya manajemen dapat menerima laporan data yang terpusat pada pengelolaan YPBI.

\section{DAFTAR PUSTAKA}

Adetokunbo A.A. Adenowo, B. A. A. (2013). Software Engineering Methodologies: A Review of the Waterfall Model and Object-Oriented Approach. International Journal of Scientific \& Engineering Research, 4(7), 427-431.

Baridwan, Z. (2011). Intermediate Accounting (8th ed.). Yogyakarta: Fakultas Ekonomika \& Bisnis UGM.

IAI. (2017). Standar Akuntansi Keuangan (1st ed.). IAI.

Kieso, Donald E, Wygandt, Jerry J, Warfield, T. D. (2010). Intermediate Accounting (13th ed.). John Wiley \& Sons Inc, Asia.

Mulyadi. (2016). Sistem Akuntansi. Salemba Empat.

Mulyani. (2016). Sistem Informasi Rumah Sakit: Analisis dan Perancangan Bandung. Abdi Sistematika.

Pasaribu, N. (2005). Akuntansi Keuangan Yayasan Dan Lembaga Nirlaba Sejenis. Jakarta: Salemba Empat.

Pawirosumarto, S. (2008). Aplikasi Komputer. Jakarta: Mitra Wacana Media.

Shatu, Y. P. (2016). Kuasai Detail Akuntansi Perkantoran (1st ed.). Jakarta: Pustaka Ilmu Semesta. 